\title{
The Features of Crime of Threat in the Iran and US Criminal Law
}

\author{
Mohammad Mehdi Rahimi \\ Correspondence: Ph.D of criminal law and criminology and Assistant Professor of Department of Humanities, \\ Faculty of Law, Islamic Azad University, Garmsar, Semnan, Iran.
}

\author{
Received: March 7, 2018 Accepted: May 13, 2018 Online Published: May 15, 2018 \\ doi:10.11114/ijlpa.v1i1.3272 \\ URL: http://dx.doi.org/10.11114/ijlpa.v1i1.3272
}

\begin{abstract}
Threat is one of behaviors which punishment is considered for it in the criminal law of Iran and US. The importance of investigating on crime of threat is where, persons and civilians in accordance with domestic laws and international instruments have the very important right as "freedom of speech" and the mentioned right violation is accompanied by criminal sanctions, on the other hand, some words or committing a specific behavior by them and according the same rules is banned and considered as is criminal threats. Nevertheless, laws of both countries have adopted different approaches in regards to terms of realization of the crime and its various manifestations. Knowing the characteristics of the crime play a significant role in explaining and analyzing criminal behavior and compliance with legal cases. Some of these features in the laws of both countries explicitly and others have been stated implicitly. The lack of clear rules regarding certain characteristics of the threat, made it difficult that jurists, judges and lawyers to understand these features. Therefore, in this paper determine the characteristics of the threat in the Iran an US law.
\end{abstract}

Keywords: threat, fear, intimidation, deliberately, crime

\section{Introduction}

By examining definitions in the regards threat, including legal and non-legal definitions, well determined that none of the definitions proposed to be comprehensive and consider all elements of the crime of threat in the providing a definition of it. Some are encounter with difficulty in explaining the moral element of this crime and committed intentionally did not mention and some others faced by defects in material elements and express all components of the material element of the crime, including physical behavior, peripheral conditions of crime and result. (Jafari Langroodi, 2003, p351) Thus, expression of a precise definition of the crime threat requires an understanding of the characteristics of this crime. Now, by considering the provided definitions in regards to threat, including literal and technical as well as taking into account the effective elements in threat such as audience, topic and spiritual element, the threat can be defined as follows:

"Announcement of intention to inflict harm or loss on physical integrity or property or honor or dignity of persons or close relatives are called threat."

With regard to the above definition the structure characteristic of the crime threat can be contained, threat audience, types and instances of threat. With expressing the characteristics, the audiences and the types of threats can realize the similarities and differences of the crime threat in Iran and the United States of America Rules. In the other words, in order to explain the strengths and weaknesses of the crime of threat in criminal law of Iran and US, the structure of mentioned crime in both countries should be examined. The most important items of crime of threat structure should be as follows: First; the crime of threat properties that are often identical in both countries. Second; audiences of threat that can be contained natural and legal persons. Third, the kinds of threats that although is not stipulated in the criminal law of Iran and US and both countries' criminal law have protested to it less. Any threatening behavior, require punishment and in a sense is not a criminal threat and threatening behavior should be effective to all attributes and features. As in some trial and appellate courts of United States of America and Iran is noted, any threatening behavior does not result in a verdict. Thus, under this section, we will explain the most important aspects of criminal threat.

\section{The Lack of Need to Use Means}

Criminal law do not consider the realization of threat conditional on the use of special means. In the other words, we can say that in the committing the threat crime the legislator did not consider use of a special means. The reason for 
such an approach can be expressed as follows that at the top of 669 article of the Islamic Penal Code (Discretionary punishments 02/03/1375) legislator has stated: "If a person in any way are threaten another to kill, or to inflict bodily harm upon or honor or financial losses and or expose the secret to themselves or his relatives, with regard to this issue whether for money or property or the demand of any work to have leave them or not, he/she will be convicted 74 lashes or imprisonment from two months to two years."

Use of the term "in any way" in the article above, realization crime of the threat is not confined to a particular means (Aghaeinia, 2016, p. 205) and threat could be done by no means. Thus threats can be oral, written and behavioral. The condition in US is the same and accepting verbal threat and penalties for its instances in criminal cases indicate that the realization of the threat in the US is not subject to special equipment. For example, it can be noted that Article 422 of the California Penal Code provides: (a) Any person who willfully threatens to commit a crime which will result in death or great bodily injury to another person, with the specific intent that the statement, made verbally, in writing, or by means of an electronic communication device, is to be taken as a threat, even if there is no intent of actually carrying it out, which, on its face and under the circumstances in which it is made, is so unequivocal, unconditional, immediate, and specific as to convey to the person threatened, a gravity of purpose and an immediate prospect of execution of the threat, and thereby causes that person reasonably to be in sustained fear for his or her own safety or for his or her immediate family's safety, shall be punished by imprisonment in the county jail not to exceed one year, or by imprisonment in the state prison... .

As seen in this Act, threating the other orally is also punishable. In addition, Article 211.3 of the Model penal Code of United States of America in explaining the threat have been stated: «A person is guilty of a felony of the third degree if he threatens to commit any crime of violence with purpose to terrorize another or to cause evacuation of a building, place of assembly, or facility of public transportation, or otherwise to cause serious public inconvenience, or in reckless disregard of the risk of causing such terror or inconvenience. » (Dubber, 2002, 231)

In this article there is also no mention of special equipment and the mere threating of other violent crime have taken place whether by speech alone or with items such as guns, knives etc. Nevertheless, the legislator in some cases that threat have been done in certain position by means considered to be subject to more severe punishment, it was good that the legislator had avoided from spread criminalization in regards to a criminal behavior and the use of special means or particular type of audience in note and following paragraph of law article of threat was subject to severe punishment.

\subsection{Threats with Gun}

As mentioned in accordance with criminal law of Iran and the United States of America, the realization of criminal threat does not depend to use any special equipment. However, some rules were considered a separate punishment for threatening with a weapon. Iranian criminal law in Article 617 of the Islamic Penal Code (Discretionary punishments 02/03/1375) consider the threat with a gun to be subject to penalties. This article stating:

"Anyone with a knife or any other weapons pretend or do show of strength or that means harass or blackmail or threaten others or grapple with someone, if that is not instances of enemy will be condemned to imprisonment from six months to two years and up to 74 lashes."

Thus, threaten by weapon would be under Article 617 of the Islamic Penal Code (Discretionary punishments 02/03/1375) and the threat without use of weapons under the scope of Article 669 of this law. (Norbaha, 2000, p217)

In summary, if a person merely with words or gestures or other behavior to threaten the other is Subject to Article 669 of the Islamic Penal Code (Discretionary punishments 02/03/1375) and if with weapon including firearms or cold weapon threaten another, his behavior is adaptable with Article 617 law and will be punished.

In criminal law of United States of America, it is varying to a large extent and should be investigated to what precedent this country has adopted an approach to the threats with weapons? Toledo 2001 criminal proceedings has found well the United States of America criminal law approach on the threat with weapons that judges pulled out such behavior as a threat and considered it as criminal as the Penal invasion.

This case arises out of a domestic dispute involving defendant Ryan Patrick Toledo, his wife (Joanne Ortega Toledo), and a neighbor (Marychelo Guerra). The evidence at trial, viewed in a light most favorable to the judgment, revealed the following events.

On the evening of January 9, 1998, when defendant picked up Joanne at work, an argument ensued over Joanne's speaking with her supervisor for 10 to 15 minutes when defendant was tired and wanted to return home immediately. The argument continued during the couple's drive home to their apartment. Once there, the dispute escalated. Among other things, defendant threw a telephone into a closet door, tossed a chair across a room, and punched a hole through a bedroom door, and Joanne told defendant that she did not care if he destroyed the apartment, and picked up a lamp and dropped it to the floor. Defendant told Joanne, "You know, death is going to become you tonight. I am going to kill 
you." Joanne responded that she did not care, in a manner that indicated she had given up hope, and walked away.

Soon thereafter, holding scissors over his shoulder, defendant approached Joanne. Joanne braced herself, and as defendant plunged the scissors toward her neck, she moved back. Defendant stopped the scissors inches from Joanne's skin, and said, "You don't want to die tonight, do you? You're not worth going to jail for." Defendant walked away, and Joanne then went to Marychelo's nearby apartment, crying, shaking, and appearing frightened.

Sometime later, Marychelo began to escort Joanne back to her own apartment. Defendant saw them and chased after Joanne, screaming as he went. Joanne and Marychelo ran back to Marychelo's apartment, and heard a bang, which later was discovered to have been caused by a clothes iron hitting a wall some distance away and shattering into pieces. Later that night, in statements made to an investigating officer, Joanne declared that she "was afraid that" defendant "was going to kill her." By contrast, when she testified at trial, Joanne denied that she had entertained any fear of defendant on the evening in question.

As a result of the foregoing incident, defendant was charged in an amended three-count information with (1) criminal threat against Joanne (§ 422), (2) assault with a deadly weapon (scissors) against Joanne (§ 245), and (3) assault with a deadly weapon (a clothes iron) against Joanne and Marychelo ( $\$ 245)$. The amended information also alleged, with regard to the criminal threat charge, that defendant personally had used a deadly or dangerous weapon (scissors) in the commission of that offense ( $\$ 12022$, subd. (b)(1)). In addition, the information charged that defendant had suffered a prior conviction for assault with a firearm as a basis for enhancement of sentence on the current offenses (§§ 667, subd. (a)(1), 1170.12, subds. (a)-(d)).

\subsection{Threats via Postal Communication}

The Code of Laws of the United States of America, in some of his legal materials threat by postal communication through the post office is be subject to punishment, in other words, threatening is done through postal communication or the post office, it is considered as a specific crime. The topics of martials of 876 and 877 and parts of Article 871 of the law stipulates that such a threat.

On the contrary, Iranian criminal law regardless of mailing threatening communications, merely a postal communication through computer systems or telecommunications, even in very limited cases, criminalized in accordance with Article 743 of The Islamic Penal Code (Discretionary punishments) or the same Article 15 of the cybercrime laws adopted 03.05.1388.

\subsection{Threat by Effects of Obscene and Vulgar}

Iranian criminal law has criminalized threatening behavior which take place with the use of vulgar and obscene works specifically. Such an approach is not observed in the United States of America Criminal law, although in that country the threat of sexual abuse specifically in 2242, 2243 and 2244 of Title XVIII The Code of Laws of the United States of America be subject to punish, but there is not explicit on the use of obscene works. Article 4 of the Law has dealt to How to punish those who act in the audiovisual unauthorized activity to threatening behavior by resorting to vulgar and obscene works: "Anyone abuse with vulgar and obscene works made by other, threatened him/her to reveal and publish the works and thereby committed adultery with her be sentenced to punishment for fornication by force, but if the act is committed outside of adultery and be subject to the lash, the lash will be done and if is subjected to Discretionary punishments Will be sentenced to the maximum punishment." (Ardebili, 2014, p230)

\section{Intimidation}

Certainly, the most important feature of the Penal threat can be intimidating or the same fear in the hearts of the audience and distinguish the threat that does not create such an important role seems a little difficult. The fear that in the threat Crime is considered, must comply with three concepts. First, the victim is really scared. Second, the fear creates reasonable. Finally, the fear is stable. Thus it can be said that fear can realize threat Crime that is the real, reasonable and sustainable. Nevertheless, each of these requires clarification and explanation of concepts and terms are as follows them.

\subsection{Actual Fear}

Before you can be convicted of a criminal threats charge, the prosecution must establish that the recipient of the threat actually feared for his/her safety or for the safety of his/her family. If the person laughs and replies "Yea, whatever," that's probably good evidence he doesn't take the threat seriously. But if he buys a new security system or goes into hiding, that's probably good evidence that he is really in fear.

And this requirement that the recipient of the threat believes that the threat is credible...and is therefore fearful of its execution...may be satisfied whether you deliver the threat in person or communicate it through a third party. ${ }^{12}$ This is important to understand - you may still be prosecuted for criminal threats even if you are not the person who personally 
conveys the threat. However, if the victim was fearful, the analysis turns to the next question - was that fear reasonable?

\subsection{Reasonable Fear}

Created fear in the audience by threatening behavior of the perpetrator must be reasonable, in other words behavior of the perpetrator create fear in a logical way. Here the debate is about applying objective criteria and subjective. From the perspective of subjective criteria (personal), in each case, depending on the nature of the threat and the circumstances, merely audience and fear in him is considered and do not care about other people do not feel intimidated by such behavior. This criterion contradicts the conventional fears. On the other side of a standard view, only created fear in the audience is not important, but it is something matters that typically people and most citizens feel fear by threatening behavior the perpetrator. For example, may be the audience of threat fear by expressions the perpetrator, which states that: "I want hijack the F-15 aircraft and drop a bomb on your house". But such phrases and words, does not create reasonable fear, in other words, conventional human will not be frightened by using such words. The important point to note is that the conventional fear and the ability to perform of threat subject by perpetrator are two very different things and what is important is that audience believe in the imminence of threat reasonably. For example, someone who threaten another to shooting and put his hand inside his pocket, to seem a gun is in his pocket, although he does not carry a gun, this is enough to realize the conventional threats and intimidation, because the audience expects the impending threat.

\subsection{Sustained Fear}

The exact definition of sustained fear is difficult. The best way to understand and explain the concept can be considered, is survey the audience mental state. In fact, in order to sustained fear and how long true horror and conventional will remain in the audience, specified time frame cannot be determined. But judicial decision should consider, in any case, of course the conditions and circumstances. However, sustained fear would take more than a few moments and is not instantaneous.

Now, in order to explanation of second feature of threat, intimidation and fear in the audience, we explain a criminal case in the United States of America.

\section{$\square$ Sample file authenticated as a real fear, conventional and sustained by court}

An example of Allen's case in 1995 to create sustained fear in the hearts of the audience and the subsequent realization Crime of the Penal threat.

Although the statute does not define the term, Penal Code section 422 requires that the defendant's threat cause the victim to be in "sustained fear." In this case, the defendant threatened to kill the victim and her daughter while pointing a gun at the victim. The victim telephoned the police, who arrested the defendant in approximately 15 minutes. We hold that in these circumstances, the victim's fear lasted long enough to satisfy the statutory element of "sustained fear."

Carl Frank Allen (Allen) appeals a judgment entered following a trial by the court resulting in Allen's conviction for two counts of terrorist threats (Pen. Code, $\S 422$ ), three counts of stalking (Pen. Code, § 646.9, subd. (b)), first degree residential burglary (Pen. Code, $\S 459$ ), and assault likely to produce great bodily injury and with a deadly weapon (Pen. Code, $\S 245$, subd. (a)(1)).

The above case is clear example of relevant the Penal threat and sustained fear in the audience. Allen had threatened Ms. Williams and her daughter, while his gun was pointed at him. The audience (the victim) had called the police and take approximately fifteen minutes long between the arrest of the accused and the victim call. Courts of United States of America were established such period taking into account the actual and reasonable Fear created, confirms sustained fear in the audience, thus the Penal threat has realized.

\section{$\square$ The sample file without Authentication of sustained Fear by court}

Ricky file in 2001 has posed in the juvenile court and its threat alleged had been dealt On February 2, 2000, a Welfare and Institutions Code section 602 petition was filed against appellant Ricky T. alleging that he made a felonious terrorist threat (Penal Code, $\S 422$ ) and threatened a teacher with the intent of preventing him from performing his duties $(\S 71)$.

On April 26, 2000, in a jurisdictional hearing, the parties stipulated that the matter be submitted on two police reports. The stipulation further provided that the People would not seek a felony finding and that appellant would waive any hearsay objections to the police reports. After hearing argument from the parties, the juvenile court found that appellant committed a misdemeanor terrorist threat in violation of section 422 .

\section{Being Intentional}

Other features of the crime of threat is that the perpetrator committing it deliberately. (Mirmohammadsadeghi, 2007, 
p482) In the other words, the perpetrator be aware to the issue and result of its threatening behavior and simultaneously would committing such behavior. In criminal law of Iran and United States of America, 4. one of the features of realization of the Penal threat is the perpetrator intentional behavior.

\section{Unequivocal}

Whether the threat is direct or indirect must be explicit. In the United States of America, being explicit of threat is mentioned and a feature of the criminal threat is being explicit. For example, Article 422 of the Penal Code of the State of California, in the definition of the Penal threat referred to explicitly of the perpetrator behavior.

This feature, In Ryan's case in 2002 is considered by judges of US. This means that Angry that an officer had cited him for possessing marijuana, Ryan D. (the minor) painted a picture of the officer and turned it in as a high school art class project a month later. The painting depicted the minor shooting the officer in the back of the head, blowing away pieces of her flesh and face. Finding it "scary," the instructor took it to the assistant principal's office. When the painting was shown to the officer, she became concerned about her safety.

However, to consider punishable a painting as the Penal threat is inconsistent with restricted interpretation of the substantive criminal law.

\section{Being Impending}

From the perspective of the audience committing threat should be imminent. This means that the audience presume the closest time to run by the perpetrator of threat. The imminence of threat, does not mean that the threat should be implemented at the same time, but the audience distinguish in case of failure keep up with demand or request of the perpetrator, he will be able do subject of threats at any time he will.

Actually, with the above description, it can be concluded that between imminence of threat and the real, conventional and sustained fear in the audience there is a direct relationship. If the audience threat, not recognize the imminent implementation of subject of threat, actual and reasonable Fear in him will not be formed, because conventional man not afraid by threatening statements of someone that knows he is not able conduct subject to threats. for example, suppose a prisoner sentenced to life imprisonment that Are currently serving his sentence in jail and cannot take advantage of legal institutes of imprisonment-removing such as probation and suspended jail contact with one of their accomplices outside the prison and his deputy have realized cooperated with police in arresting him and threatened to kill him and his family.

In this example, Crime threat cannot be realized, because there is no sense of impending subject to threats and consequently the perpetrator has the ability to conduct his subject of threat will not exist in the audience, in other words, it can be concluded no real, conventional and sustained fear, not formed in the audience by this threat.

Of course, on the example above, it should be noted that If the prisoner to tell his accomplice if does not cooperate whit him, one of the member of its criminal grope will find his address and then rape his wife and do sexual harassment on his young children and then kill them in the most brutal way possible, the theme is different.

In recent case, the audience understands the impending threat, but in the first example there is no such feeling. In the second example, the audience with an understanding of the defendant (the prisoner) recognizes that he has the ability of conducting his threating subject in any time and consequently the actual, conventional and sustained fear will form in him. While in the first instance, due to the absence of an imminent threat, it does not make sense in the audience.

For example, in the case of Lopez, 1999 Defendant Antonio Lopez was convicted and imprisoned for making terrorist threats. (Penal Code, § 422.) He had said to his father's girlfriend, among other things, "I'm going to get my friends out here to kill you."

The important point is that in the above case, used threat was imminent, the audience of threat (Betty) recognized that the perpetrator (Lopez) is capable of subject to threats (killing Betty) and thus greatly feared and intimidated.

\section{Being Illegal}

Other features of threat that usually is not dealt with and consequently in providing comprehensive definition of threat is ignored is being illegal of the threat.

The question that arises is that are there legal threats? The answer to this question will be positive and most important examples of legal threats can be threat of invasive from the defendant in legitimate defense and also The defendant threat by police At the time of his escape and The need to use weapons according to the law of use of weapons As well as threat other can be know the complaint against him in a court of law. In the case that the accused is fleeing And police officers with regard to the use of weapons, threatened to shoot the accused, the realization of threat crime would not be possible by considering that the behavior has been a legal and law enforcement. 


\section{Conclusion}

Eventually, it should be noted, in Iranian criminal law although the Penal threat do not Requires the use of a particular means, However, in some Instances, the most important of which are the knives or guns, Article 617 of the Islamic Penal Code (Discretionary punishments 02/03/1375), Computer systems and telecommunications and Consequently, e-mail Article 15 computer crime law 03/05/1388 And works pornographic and vulgar prepared from the audience threat. Articles 4 and 5 of the law How to punish persons for their illegal audiovisual activities. Iran threatened criminal law is not conditional on the use of certain means.

Criminal law of United States of America is the same. And the Penal threat do not require the use of specific tools, However, in some legal Substances such as Substances 876, 877, 871 of The legal codes of United States of America, the use of postage is subject to the Penal threat. Also, one of the most important of the realization of the crime threat is making the feel of terror and fear in the audience by the perpetrator behavior and if threatening behavior does not create fear in the audience Compliance with the offense of threatening behavior would be difficult. It is important to note that Three conditions must be created Fear and effective concept. in the other words Fear caused by behavior the perpetrator must be actual, conventional and sustained and if that Fear is lacking in such circumstances, Verdict will not be possible to the perpetrator. Also, in order to realize the threat Crime, Under Iranian law and America, existing the other mentioned features as intentional, being explicit, Impending and illegality is essential.

\section{References}

Aghaeinia, H. (2016). Criminal law: Crimes against persons (Felonies). Tehran: Mizan Publication.

Aghaeinia, H. (2015). Criminal law: Crimes against persons (Spiritual character). Tehran: Mizan Publication.

Ardebili, M. (2014). General criminal law. Second volume, Tehran: Mizan Publication.

Jordan, D. A. (2010). U.S Intelligence Law: A comprehensive Multimedia Law. U.S.A: Legal Publisher.

Mohammadjafar, J. L. (2003). Elements of civil law and criminal law Dictionary. Tehran: Ganj e danesh Publication.

Iraj, G. (1393). Explanation of Islamic Penal Code. Tehran:Majd Cultural Scientific Assembly.

Dubber, M. D. (2002). Criminal Law: Model Penal Code. U.S.A: Fundation Press.

Allen, M. J. (2012). Textbook On Criminal Law. U.K: Oxford University Press.

Mostafa, M. D. (2016). The rules of law: Criminal section. Tehran: Humanities publication center.

Mirmohammadsadeghi, H. (2007). Crimes against the persons. Mizan Publication.

Mirmohammadsadeghi, H. (2007). Crimes against security and public safety. Tehran: Mizan Publication.

Norbaha, R. (2000). General criminal law context. Tehran: Dadafarin publication

\section{Copyrights}

Copyright for this article is retained by the author(s), with first publication rights granted to the journal.

This is an open-access article distributed under the terms and conditions of the Creative Commons Attribution License which permits unrestricted use, distribution, and reproduction in any medium, provided the original work is properly cited. 